\title{
Nastoletnie macierzyństwo wyzwaniem współczesnych czasów
}

\section{Teenage Motherhood as a Challenge of Modern Times}

\begin{abstract}
Adolescence tends to be perceived as a time of seeking autonomy and independence, as well as of reorganizing one's social functioning and forming one's identity. Young people wish for their concepts of themselves and their future lives to remain cohesive and stable.

Undoubtedly, motherhood belongs to one of the most important experiences which shape a woman's life in a certain way. It is clearly connected with the biological nature as well as with certain sociocultural expectations. Teenage motherhood tends to be perceived as a serious problem in social discussions. Becoming a mother before the coming of age is connected with the necessity of accepting responsibility for the child and it contributes to a change of the previous way of functioning.

The aim of the paper is to present the specificity of the period of adolescence, teenage motherhood, difficulties and the role of support for the young mothers.
\end{abstract}

Keywords: teenage mothers, adolescence, support, stigmatization, motherhood, mother

Słowa kluczowe: nastoletnie matki, adolescencja, wsparcie, stygmatyzacja, macierzyństwo, matka

\section{WPROWADZENIE}

Macierzyństwo to istotne zadanie rozwojowe w życiu kobiety. Bywa określane jako najistotniejsza i najbardziej znacząca rola, posłannictwo, centralny, dominujący element kobiecości (Dzwonkowska-Godula, 2009; Fromm, 1971). Czas niezwykle piękny (odkrywanie siebie, swoich możliwości, a także wzmacnianie wytrwałości, skuteczności i sprawczości), ale również bardzo wymagający (uczenie się nowej roli, przyjmowanie kolejnych obowiązków) (van Vugt, Versteegh, 2020; Mangeli i in. 2018; Cox i in., 2021; Stern, 2018). Psychologiczne przystosowanie do macierzyństwa przebiega łatwiej w przypadku pozytywnego nastawienia kobiety do ciąży i przyszłej roli (Przybyła-Basista $\mathrm{i}$ in., 2020). Wynika to $\mathrm{z}$ większej świa- domości zachodzących zmian i zmniejszonego przed nimi lęku.

Coraz częściej młode kobiety przejawiaja mentalność indywidualistyczną, wyrażającą się w wyborze celów życiowych, poglądów, sposobu zachowania oraz budowania relacji z innymi (Dankiewicz-Berger, Cendal, 2019; Dobrołowicz i in., 2019; Smyth, 2020). Współcześnie zauważalne jest przejście „od pojmowania macierzyństwa w kategoriach bardziej biologicznych do coraz bardziej świadomego i systemowego traktowania powinności matczynych" (Bartkowiak, 2015, s. 292). Obecnie młode kobiety coraz częściej odkładają decyzję o posiadaniu dzieci na bliżej nieokreśloną przyszłość. Przyczyn tego zjawiska należy upatrywać między innymi w kontrolowaniu płodności (postępie medycyny, farmakologii), wzroście 
świadomości społecznej dotyczącej zagrożeń wynikających z przedwczesnego macierzyństwa, realizacji celów związanych z uzyskiwaniem wszechstronnego wykształcenia czy znalezieniem dobrze płatnej pracy (Dziewanowska, 2019; Żelazkowska, 2016).

Macierzyństwo może mieć również charakter nieplanowany, kiedy kobiety nie są gotowe, by zostać matkami. Ciąże nastoletnie są zjawiskiem ogólnoświatowym, występującym w krajach o niskich, średnich i wysokich dochodach. Według raportu World Health Organization (2020) każdego roku około 12 milionów dziewcząt w wieku 15-19 lat i co najmniej 777 tysięcy poniżej 15. roku życia rodzi dzieci. W wielu państwach nastoletnie macierzyństwo bywa postrzegane przez pryzmat negatywnych konsekwencji dla matki i dziecka (Jones i in., 2019). Najczęściej zwraca się uwagę na ubóstwo, bezrobocie, małą zaradność nastolatek. Coraz więcej prowadzonych badań wskazuje również na piętno stygmatyzacji oraz uprzedzeń wobec młodocianych matek (Ellis-Sloan, Tamplin, 2019).

Nastoletnie ciąże w większości przypadków są określane jako wydarzenia kryzysowe z powodu podwyższonego poziomu stresu, niskiego poczucia własnej wartości, osamotnienia, niezrealizowanych celów edukacyjnych i zawodowych. Niekiedy wczesne macierzyństwo może się stać ,katalizatorem pozytywnej zmiany tożsamości" (Mulherin, Johnstone, 2015, s. 297), ,niezwykłym punktem zwrotnym” (Barn, Mantovani, 2007, s. 239), okazją do integracji społecznej. W swoich badaniach Maasoumeh Mangeli, Masoud Rayyani, Mohammad Ali Cheraghi i Batool Tirgari (2018) wykazali, że wczesne rodzicielstwo może się przyczyniać do poszerzania samowiedzy, wzrostu poczucia własnej wartości, dojrzałości psychicznej i emocjonalnej oraz zwiększenia zdolności wychowawczych dziewcząt.

Czynnikiem sprzyjającym takim tendencjom może być ustalenie profesjonalnych strategii pomocowych oraz form wsparcia dla młodocianych matek. Problematyka nastoletniego macierzyństwa jest często pomijana w społecznych dyskusjach. Brak adekwatnego poradnictwa i odpowiednich długoterminowych rozwiązań oraz bezradność systemów wobec skutecznych form pomocy (niedobór profesjonalnego systemu pomocy instytucjonalnej na przykład dla małżeństw nieletnich zawartych za zgodą sądu) stanowią poważne utrudnienie dla funkcjonowania młodocianych matek i ich dalszego rozwoju.

\section{SPECYFIKA ROZWOJU W OKRESIE ADOLESCENCJI}

Okres dorastania jest ważnym punktem w rozwoju młodego człowieka. Bywa postrzegany jako czas poszukiwania i gromadzenia doświadczeń psychicznych, intelektualnych oraz społecznych. Cechami typowymi tego etapu są: eksperymentowanie, abstrakcyjność myślenia, planowanie przyszłości, rozwój empatii, idealizm, ale również niedojrzałość w podejmowaniu decyzji (Chemutai i in., 2020). To także czas formowania tożsamości, dokonywania istotnych wyborów życiowych (Al-Kloub $\mathrm{i}$ in., 2019). Adolescencja uznawana jest za jeden z ważniejszych etapów życia człowieka z powodu stopniowego usamodzielniania się jednostki i wchodzenia w szerszy system społeczny.

Zdaniem Roberta Jamesa Havighursta (1948) młody człowiek powinien w tym okresie nawiązać bardziej dojrzałe relacje z rówieśnikami, nauczyć się funkcjonować w rolach społecznych, zaakceptować i w pełni wykorzystać możliwości związane z własnym rozwojem, uzyskać niezależność emocjonalną od rodziców oraz przygotować się do aktywności rodzinnej, zawodowej i społecznej. W okresie dorastania młodzież odchodzi od dziecięcych identyfikacji, wzorców i zaczyna coraz bardziej dostrzegać własną indywidualność i niepowtarzalność. W tym czasie wzrasta znaczenie grupy rówieśniczej. Tworzone kontakty zmieniają się pod względem ilościowym (na przykład spędzanie większej ilości czasu z przyjaciółmi, znajomymi) oraz jakościowym (większa otwartość, intymność) (Rubin i in., 2006). Relacje rówieśnicze stają się przestrzenią młodzieńczej identyfikacji, konfrontacji, a także zapewniają poczucie bezpieczeństwa. Młodzi ludzie w okresie dorastania 
stają się niezwykle krytyczni. Często podważają autorytet osób dla siebie znaczących. Dążą do budowania relacji partnerskiej z rodzicami. Kontakty z bliskimi stanowią dla nich ważne źródło wsparcia.

W okresie dorastania występują problemy $\mathrm{z}$ akceptacją siebie, kształtowaniem indywidualnej tożsamości, akceptacją rówieśniczą, a także pozostawaniem pod presją społeczną mogącym przyczynić się do wystąpienia wewnętrznych konfliktów i niepokojów (Borecka-Biernat, 2011). Często o poziomie trudności danej sytuacji decydują uwarunkowania zewnętrzne (rodzaj zadania, wpływ otoczenia), ale również wewnętrzne (samoocena, poziom aspiracji). Okresowi dorastania towarzyszy wiele doświadczeń, które są nieznane i trudne dla młodych ludzi. Posiadane schematy poznawcze, dotychczasowe strategie adaptacyjne w obliczu konkretnych zdarzeń okazują się niewystarczające. Zadaniem nastolatka staje się wypracowanie nowych sposobów reagowania na zaistniałą sytuację.

\section{SEKSUALIZACJA WSPÓLCZESNEJ KULTURY A FUNKCJONOWANIE MLODZIEŻY}

Rozwój seksualny jest naturalną częścią okresu dojrzewania. Stanowi ważny etap rozwoju biopsychospołecznego. W tej fazie są podejmowane różne formy ekspresji seksualnej stanowiące pewien sposób uspołecznienia seksualności. Proces nabywania doświadczeń seksualnych obejmuje romantyczne związki, randkowanie, a także inicjację. Nastoletnie relacje uczuciowe to wydarzenia normatywne, pomagające młodym ludziom osiagnąć intymność w okresie dorosłości (Connolly, McIsaac, 2009). Doświadczenia seksualne są zazwyczaj poprzedzane randkami, a związki romantyczne stanowią wstęp do interakcji seksualnych (Furman, Shaffer, 2003).

W adolescencji dostrzegalny jest wyraźny rozdźwięk między uczuciowością a pożądaniem (Kernberg, 1998). We wczesnej fazie dorastania relacje romantyczne nastolatków są skoncentrowane głównie na atrakcyjności fizycznej.
Głównym motywatorem tych kontaktów staje się system afiliacji i seksualności, a nie przywiązanie (Scharf, Mayseless, 2007).

Współczesna kultura Zachodu coraz częściej zaczyna postrzegać człowieka jako istote seksualną. Seksualizacja jest niebezpiecznym zjawiskiem, ponieważ podkreśla, że „wartość osoby wynika wyłącznie z jej atrakcyjności seksualnej lub zachowania, z wyłączeniem innych cech" (American Psychological Association, 2007, s. 1). Poważny problem w ostatnich latach stanowi seksualizacja dziewcząt. Obecnie coraz częściej proces ten jest traktowany jako występujący w dziewczęcej codzienności wyznacznik przemian oraz aberracja procesu socjalizacji dziewcząt (nieadekwatny do wieku poziom rozwoju psychoseksualnego; Leksy, 2020). Wizerunek młodych dziewcząt w mediach najczęściej podkreśla ich atrakcyjność seksualną oraz dostępność (Ward i in, 2016). Badania wykazały, że taki obraz medialny może zwiększać ryzyko depresji i samouprzedmiotowienia oraz obniżać samoocenę i zadowolenie $\mathrm{z}$ własnego ciała (Zurbriggen i in., 2011). $\mathrm{W}$ ostatnim czasie niepokojącym zjawiskiem jest również efekt Lolity polegający na uwodzeniu chłopców oraz mężczyzn przez młode dziewczyny. Zachowania prowokacyjne wiążą się z: charakterystycznym sposobem poruszania się, specyficznymi gestami oraz wypowiedziami. Zdaniem Meenakshi Gigi Durham „Lolita stanowi archetyp szczególnej kategorii dziewczynek, które wodzą na pokuszenie, nie zdając sobie z tego sprawy, i roztaczając swój czar nieświadomie, czy wręcz wbrew swojej woli-mają wielką siłę przyciągania, która wcale nie wynika, czy nie musi wynikać z atrakcyjnej urody" (Durham, 2010, s. 27). Seksualizacja może doprowadzić do zaburzeń rozwoju seksualnego, w tym wytworzenia nierealistycznych oczekiwań w sferze seksualnej.

W ostatnich latach ,pęd ku dorosłości” jest coraz częściej obserwowany wśród młodzieży. Dużą rolę w rozwoju tego trendu odgrywa obniżenie wieku inicjacji seksualnej, sposób postrzegania aktywności seksualnej jako pozbawionej odpowiedzialności, skoncentrowanej głównie na przyjemności (Skowroński, 2013). Aktywność seksualna jest traktowana przez 
młodzież jako bezproblemowa i dobra zabawa (Szukalski, 2010). Wyniki badań HBSC 2014, wskazują, że inicjację seksualną odbyło 17,4\% ankietowanych piętnastolatków (w tym 18,5\% dziewcząt i 16,0\% chłopców) (Mazur, 2015). Według badań HBSC przyczynami wczesnych inicjacji w przypadku dziewcząt są: używki, wagarowanie oraz spędzanie licznych wieczorów $\mathrm{w}$ towarzystwie rówieśników, a w przypadku chłopców: używki, wagarowanie, uczęszczanie do zasadniczej szkoły zawodowej, słaby nadzór ze strony matki. Presja rówieśnicza oraz wzrastające zainteresowanie płcią przeciwną prowadzi do podejmowania eksperymentów z aktywnością seksualną (Mushwana i in., 2015).

Wczesne inicjacje seksualne zwiększają ryzyko występowania innych zachowań ryzykownych, na przykład współżycia z wieloma partnerami, osobami obcymi, prostytucji (Imacka, Bulsa, 2012). Nastolatki często budują poczucie własnej wartości, opierając się na swojej atrakcyjności, intensywności kontaktów czy akceptacji rówieśników. Złe relacje z rodziną lub ich brak oraz niskie poczucie własnej wartości sprzyjają nawiązywaniu przypadkowych kontaktów seksualnych. Pozytywne relacje w rodzinie, zaspokajanie potrzeb bezpieczeństwa, przynależności i samorealizacji mogą być czynnikami chroniącymi przed podejmowaniem wczesnego współżycia seksualnego.

W ostatnim czasie nowoczesne technologie komunikacyjne oraz informacyjne miały się przyczynić do poprawy intymnej komunikacji między młodymi ludźmi (Barrense-Dias i in., 2017), ale wbrew pierwotnym założeniom są one coraz częściej wykorzystywane do wysyłania zdjęć lub filmów o treści seksualnej lub erotycznej (Galovan i in., 2018). Postępująca kultura obnażania się przyczynia się do rozwoju sekstingu. Traktowany on bywa przez młodzież jako ,zabawny sposób na flirtowanie” i element romantycznego związku (Hasinoff, 2013). Młodzi ludzie dzięki rozwojowi technologicznemu rozpoczynają eksplorację oraz eksperymentowanie z seksualnymi fantazjami. Dziewczęta coraz bardziej angażują się w wymianę elektroniczną treści o zabarwieniu seksualnym, przesyłając swoje nagie lub półnagie zdjęcia (Ringrose i in., 2013). Kathy Martinez-Prather i Donna
Vandiver (2014) uznają seksting za metodę komunikacji na temat początkowych doświadczeń seksualnych oraz konsekwencji nastoletnich ciąż. Do głównych motywacji rozwoju sekstingu zalicza się presję rówieśniczą oraz potrzebę seksualnej eksploracji, wzmocnienia poczucia własnej wartości, zyskania aprobaty społecznej i wyrażenia siebie (Döring, 2014). Niektóre dziewczyny zgadzają się na ,niechciany" seksting, ponieważ uważają, że jest to rodzaj pewnej ,zgodności seksualnej” lub „niepożądanej ceny", którą muszą zapłacić, aby utrzymać pozytywne relacje z partnerem (Dodaj, Sesar, 2020). Przyczynia się on do instrumentalizacji i uprzedmiotowienia ciała kobiety, wzrostu lęku, powstania depresji (van Oosten, Vandenbosch, 2017). W swoich badaniach José Luis Jasso Medrano, Fuensanta Lopez Rosales i Manuel Gámez-Guadix (2018) wskazują, że seksting zwiększa ryzyko wiktymizacji, cyberprzemocy oraz samobójstw wśród młodzieży. Prowadzi również do sekstoracji związanej z groźbą rozpowszechniania i ujawniania treści o charakterze intymnym, zawstydzającym, bez zgody osoby, celem uzyskania dodatkowych korzyści, na przykład wymuszenia zgody na seks (Patchin, Hinduja, 2020).

\section{NASTOLETNIE MATKI}

Nastoletnie matki stanowią niejednorodną grupę pod względem wieku, rozwoju biologicznego, psychicznego, społecznego oraz statusu prawnego i edukacyjnego. Według World Health Organization (2016) nastoletnimi matkami określa się młode dziewczęta, które podejmują rolę rodzicielską przed 19. rokiem życia. W Polsce przez długi czas zagadnienie to nie stanowiło przedmiotu odrębnych badań naukowych. W 1990 roku liczba urodzeń przez nastoletnie matki wynosiła 30/1000, a w 2018 roku - 10/1000 (Rocznik Demograficzny, 2019). Obserwowane trendy spadkowe nastoletnich ciąż wiążą się z rozpowszechnieniem antykoncepcji, działaniami edukacyjnymi oraz kampaniami społecznymi (Jalanko i in., 2021). Zwolennicy edukacji seksualnej dążą do tego, by obejmowała ona wiele tematów, między in- 
nymi rozwój człowieka, relacje, seksualność, zdrowie, zachowania reprodukcyjne oraz kulturę (Mezmur i in., 2021). W ostatnim czasie podkreślana jest rola kompleksowej edukacji w zakresie zdrowia seksualnego, przyczyniająca się w znaczący sposób do ograniczania ryzykownych zachowań młodzieży i zwiększania działań ochronnych (Pavelová i in., 2021).

Nastoletnie macierzyństwo bywa określane jako wydarzenie niepunktualne i krytyczne. Występuje ono zbyt wcześnie, wziąwszy pod uwage rozwój człowieka, i może prowadzić do pewnych trudności w funkcjonowaniu. Młodociani rodzice doświadczają w tym czasie dwóch kryzysów: normatywnego (związanego z kształtowaniem się tożsamości, światopoglądu, systemu wartości) oraz nienormatywnego (związanego z realizacją ról rodzicielskich i społecznych: córki/syna, uczennicy/ucznia, partnera/partnerki) (Bakiera, Szczerbal, 2018; Sadler, 2011).

Zgodnie z teorią cyklu życia doświadczenia życiowe i ich czas wpływają na zdrowie i rozwój społeczny (Elder, 1998). Ginny Brunton, Meg Wiggins, Ann Oakley (2011) w swoich badaniach przeprowadzonych wśród respondentek w różnym wieku wykazały, że macierzyństwo jest fizycznie, psychicznie i emocjonalnie przytłaczające, dodatkowo kobiety często kwestionuja swoją zdolność do bycia dobrymi matkami. Macierzyństwo ma znaczący wpływ na relacje z rówieśnikami i partnerami intymnymi, które są również uznawane za ważne zadania rozwojowe w okresie dojrzewania (Brunton i in., 2011; Sadler, 2011). Kobiety, które rodzą dzieci jako nastoletnie matki, przez dłuższy czas mają trudności ze zdrowiem fizycznym i psychicznym (Maslowsky i in., 2021). Ze statystyk wynika, że nastoletnimi matkami zostają dziewczęta wcześnie dojrzewające (Bidzan, 2013). Dostrzegalne są $\mathrm{u}$ nich problemy osobiste w zakresie menstruacji i akceptacji zmieniającej się sylwetki oraz większa podatność na zachowania ryzykowne (na przykład uzależnienia, wczesne współżycia seksualne). Ponadto wstępują u nich niskie poczucie własnej wartości i skuteczności, nieosiągnięte cele edukacyjne, zawodowe, a czasami także samotność (Mulherin, Johnstone, 2015; Pavelová i in., 2021).
Kryzys doświadczany w sytuacji nastoletniego macierzyństwa wiąże się z poczuciem bezradności, chaosu, zamętu, podwyższonym napięciem, dezorganizacją działania, utrudnieniami w codziennym funkcjonowaniu (Żelazkowska, 2016). Stres towarzyszący młodocianym dziewczynom w ciąży w znaczący sposób wpływa na ich funkcjonowanie psychiczne. Często pojawiają się u nich obniżenie nastroju, myśli depresyjne, pesymistyczna wizja świata oraz własnej przyszłości.

Ciąże nastoletnie budzą niepokój z powodu licznych konsekwencji, między innymi trudności zdrowotnych matki i dziecka, aborcji, samotnego macierzyństwa, małego zaangażowania ojców w wychowanie dzieci. Sama wiadomość o ciąży wzbudza u nastolatek szok, niedowierzanie, złość, strach, poczucie winy (Bidzan, 2013). Czasami zdarza się, że przyszłe matki nieakceptujące ciąży przyczyniają się do poronień przez stosowanie używek, zadawanie sobie fizycznych obrażeń. Młode dziewczęta nie chcą również współpracować z personelem medycznym w trakcie ciąży, porodu i połogu. Nie przychodzą regularnie na wizyty kontrolne. U nastoletnich dziewcząt występuje także zwiększone ryzyko powikłań, na przykład samoistne poronienia, infekcje dróg moczowych, przedwczesne odklejenie łożyska, rzucawki (van Vugt, Versteegh, 2020).

Stygmatyzacja i dyskryminacja to kolejny ważny problem młodych matek (Maslowsky $\mathrm{i}$ in., 2021). Nieletnie dziewczęta są świadome problematycznego obrazu siebie. Stygmatyzacja społeczna dla wielu z nich wiąże się z ograniczeniem aktywności oraz dotychczasowych relacji, a nieprzychylne spojrzenia i obraźliwe komentarze wywołuja poczucie izolacji. Stygmatyzacja prowadzi również do obniżenia poczucia własnej wartości (Ellis-Sloan, Tamplin, 2019). Elizabeth Whitehead (2001) stwierdziła, że piętno społeczne wykracza poza ,wygląd”, prowadząc do procesu „śmierci społecznej”.

Mariola Bidzan (2013), Alicja Skowrońska-Zbierzchowska (2010), Maasoumeh Mangeli, Masoud Rayyani, Mohammad Ali Cheraghi, Batool Tirgari(2018), Christine Wayua Musyimi, Victoria Mutiso, Darius N. Nyamai i Ikenna Desmond Ebuenyi, David Ndetei (2020) wskazuja. 
że nastoletnie macierzyństwo często wiąże się także $\mathrm{z}$ różnymi trudnościami, między innymi o charakterze edukacyjnym (przerywanie, odraczanie edukacji), psychologicznym (depresja, niedojrzałość emocjonalna, nieodpowiedzialność, lęk, niepokój, poczucie bezradności, bezcelowości własnego życia), społecznym (rozpad związku, brak wsparcia) (Włodarczyk, 2009). U młodych dziewcząt występują silne mechanizmy obronne - zaprzeczanie, izolacja, wycofanie (Bidzan, 2013).

W okresie poporodowym nieletnie matki zmagają się z problemami takimi jak zmęczenie, krótki pobyt na oddziale po porodzie, brak doświadczenia w opiece, czynnościach pielęgnacyjnych dziecka. Trudności te stanowia również wyzwanie dla położnych, zwłaszcza w zakresie zapewniania zdrowia, edukacji, motywacji, wsparcia i wzmocnienia samooceny. Maasoumeh Mangeli, Masoud Rayyani, Mohammad Ali Cheraghi i Batool Tirgari (2018), w badaniach jakościowych przeprowadzonych wśród 16 nastolatek, które urodziły pierwsze dziecko przed 19. rokiem życia, wykazały, że największym wyzwaniem dla dziewcząt jest wzięcie odpowiedzialności za własne dziecko. Najpoważniejszymi problemami są brak czasu oraz zmęczenie fizyczne i psychiczne. Młode matki w szczególny sposób oczekiwały wsparcia i pomocy ze strony innych. Przedwczesne macierzyństwo stawia młodą dziewczynę przed licznymi wyzwaniami fizycznymi, psychologicznymi, społecznymi i duchowymi. Ukazuje wszelkie braki w zakresie umiejętności planowania, podejmowania decyzji, trudności w akceptacji siebie, konflikty ról, kryzysy w rodzinie i brak wsparcia (Raley i in., 2012; Vincent, Alemu, 2016).

Przyczyn nastoletniego macierzyństwa najczęściej upatruje się w czynnikach społecznych i ekonomicznych. Do pierwszej grupy zalicza się relacje $\mathrm{z}$ rówieśnikami i nauczycielami, sposób realizacji aktywności własnej. Silnym predyktorem podejmowania wczesnej aktywności seksualnej są złe relacje z rodzicami, ciekawość, presja ze strony grupy rówieśniczej czy moda (Mushwana i in., 2015; Steinberg, 2014). Coraz bardziej postępująca laicyzacja życia społecznego, upowszechnienie przedmałżeńskich praktyk seksualnych oraz nieadekwatna do zachodzacych przemian społecznych edukacja seksualna, wpływ mass mediów, szczególnie w zakresie instrumentalizacji oraz uprzedmiotowienia relacji seksualnych, a także osłabienie kontroli społecznej przyczyniają się do wstępowania nastoletnich ciąż (Deręgowska-Majorczyk, 2012). Zdaniem Urszuli Kempińskiej (2012) przyczyn nastoletniego macierzyństwa należy upatrywać w akceleracji rozwoju, niskim poziomie wykształcenia (młodzież szkół zawodowych wcześniej rozpoczyna aktywność seksualna), ustosunkowaniu do religii (młodzież z pozytywnym ustosunkowaniem do religii później inicjuje aktywność seksualna), sytuacji rodzinnej (trudna sytuacja rodzinna związana między innymi z nieobecnością ojca w domu, rozwodem rodziców) i braku asertywności.

\section{NASTOLETNI OJCOWIE}

Nastoletnie ojcostwo jest tematem często pomijanym w społecznych dyskursach z powodu zaprzeczania przez nieletnich chłopców swojemu ojcostwu. Młodociani ojcowie są określani jako nieodpowiedzialni, niekontrolowani i niedojrzali (Mukuna, 2020). Ponadto bywają wykluczani z życia swoich dzieci, ponieważ uchodzą za osoby obojętne wobec potomstwa, zaniedbujące role rodzicielskie (Matlakala i in., 2018).

Nastoletnie ojcostwo ma wiele negatywnych konsekwencji edukacyjnych, finansowych, społecznych oraz zdrowotnych dla mężczyzn i ich dzieci. Młodzi chłopcy muszą przejść dwa etapy w rozwoju: okres dorastania i ojcostwa. Sytuacja ta często doprowadza do niepokoju, którego przyczyną jest brak gotowości do przyjęcia odpowiedzialności za własne dziecko. Wsparcie ze strony rodziców może się przyczynić do zaangażowania nastoletnich ojców w relacje z własnymi dziećmi i do poprawy ich zdrowia psychicznego (Hunt i in., 2015). Zawarcie związku małżeńskiego często jest dla nastoletnich mężczyzn czynnikiem chroniącym ich przed uzależnieniami czy działaniami przestępczymi (Mukuna, 2020). Nastoletni żonaci 
ojcowie, jak wynika z badań Moniki Landers, Ojmarrha Mitchella, Eriki Coates (2015), mieszkają z dziećmi i podejmują próby angażowania się w opiekę nad nimi. Większość młodocianych ojców pragnie zapewnić potomstwu środki finansowe, chce być „dobrymi ojcami” pomimo trudnej sytuacji ekonomicznej (Paschal i in., 2011).

Ojcostwo jest przytłaczającym doświadczeniem, które wymaga umiejętności przystosowania się do zupełnie nowej sytuacji życiowej i większej odpowiedzialności (Premberg i in., 2008). Pewność siebie ojców co do umiejętności i zdolności potrzebnych do bycia ojcem zależy od ich postrzegania własnych kompetencji do pełnienia roli rodzicielskiej (Ferketich, Mercer, 1995). Atcharawadee Sriyasak, Anna-Lena Almqvist, Chaweewan Sridawruang, Wanwadee Neamsakul i Elisabet Häggström-Nordin (2016) w swoich badaniach przeprowadzonych na grupie starszych i nastoletnich ojców wykazały, że młodociani ojcowie przejawiali mniejsze zaangażowanie $\mathrm{w}$ działania związane $\mathrm{z}$ opieką nad dziećmi.

Bycie ojcem bywa opisywane jako proces dojrzewania (Premberg i in., 2008). Dojrzałość psychiczna obejmuje niezależność, produktywność, stabilność, akceptację siebie (Seglow, Canham, 2002). Czynniki takie jak wiek, priorytety, pochodzenie, status społeczno-ekonomiczny, gotowość do podjęcia roli rodzicielskiej kształtują relację ojców z dziećmi oraz ich poziom zaangażowania w okresie ciąży partnerek i po ciąży (Henderson, Redshaw, 2013). Badania prowadzone przez Lisę Primus (2017) wskazują, że wielu młodych ojców jest stanu wolnego, nie otrzymuje wsparcia od swoich rodziców w opiece nad własnym dzieckiem.

Oluwatoyin Adewole i Oluwaseun Otubanjo (2020) w badaniach przeprowadzonych na mężczyznach w wieku od 18 do 21 lat wykazały, że badani postrzegali nastoletnią ciążę jako trudne i negatywne doświadczenie dla nastolatki. Młodzi mężczyźni stwierdzali, że nieplanowana ciąża byłaby ,przeszkodą w osiagnięciach akademickich" i ,zrujnowałaby ich życie”. Niektórzy nie zdecydowali się być młodymi ojcami z powodu stresu związanego z rodzicielstwem, alimentami i innymi zobowiązaniami finansowymi. Siphiwe Madlala, Maureen Sibiya i Thembelihle Ngxongo (2018) wykazały z kolei, że młodzi mężczyźni często czują się wykluczeni w sytuacji ciąży partnerki. Mają poczucie, że jest to doświadczenie dostępne tylko dla kobiet.

\section{ROLA WSPARCIA DLA NASTOLETNICH MATEK}

Trajektorie życia młodych matek „,w dwóch różnych światach", jak określa to Donna Clemmens (2003, s. 96), w dużym stopniu zależą od czynników kontekstowych, takich jak sytuacja przed ciążą i w trakcie ciąży, zasoby osobiste oraz doświadczane wsparcie nieformalne i formalne (Pavelová i in., 2021). Młode dziewczyny w szczególny sposób wymagają wsparcia od partnera i rodziny, chroniącego je przed wykluczeniem społecznym (Baxter i in., 2021).

Liczne badania pokazuja, że nastoletnie matki, które tworzą dobre relacje $\mathrm{z}$ rodziną, mają przyjaciół i korzystają ze wsparcia organizacyjnego, znacznie lepiej radzą sobie z nową rolą (Żelazkowska, 2018). Wsparcie spełnia tutaj funkcję ochronną i neutralizująca, dostarcza środków finansowych. Zmienia też postrzeganie trudnej sytuacji. W doświadczaniu takiej sytuacji ważne jest też korzystanie ze wsparcia osób będących w podobnym położeniu. Pomoc rodzinna może obejmować potencjały indywidualne, zasoby systemowe, ekonomiczne (Zbierzchowska, 2020). Pierwsze to cechy jednostkowe, umiejętności rodziców i dzieci, w tym na przykład wykształcenie, inteligencja, optymizm, stan zdrowia. Zasoby systemowe wiążą się z więziami emocjonalnymi, tradycyjnymi, systemem wartości, rytuałami, dobrą komunikacją, zdolnościami adaptacyjnymi. Ekonomiczne zasoby to dochody członków rodziny, mieszkanie (Zbierzchowska, 2020).

Elizabeth Tracy i James Whittaker (1990) w trakcie badań dostrzegli, że ważnymi elementami sieci pomocowych są między innymi obecność ojca dziecka i rodziny oraz samo doświadczenie rodzicielstwa. Odpowiednie wsparcie może pomóc młodym ludziom przejść w okres dorosłości i rodzicielstwo. Ponadto przyczynia 
się w pewien sposób do zwiększenia poczucia własnej wartości, skuteczności, pozytywnego nastawienia w kształtowaniu tożsamości (Graham, McDermott, 2005). Szczególne znaczenie dla nastoletnich matek ma wsparcie otrzymywane od własnych matek oraz partnerów. Wsparcie bliskich motywuje do ukończenia szkoły, zmiany siebie (młoda dziewczyna zaczyna sobie zdawać sprawę, że będzie wzorem dla swoich dzieci). Obecność ojca dziecka i jego zaangażowanie w opiekę i wychowanie wyraźnie zmniejszają poziom stresu i niepokoju oraz sprzyjają zadowoleniu młodej matki. Badania Carola Roye i Sophie Balk (1996) wskazuja, że wsparcie materialne, jak i niematerialne ze strony ojca dziecka znacząco przyczynia się do wzmocnienia samooceny i zadowolenia nastoletniej matki.

Pomoc otrzymywana od matek sprzyja poczuciu miłości oraz stabilności. Pozytywne relacje z matką obniżają ryzyko depresji, przyczyniają się do rozwijania umiejętności rodzicielskich oraz kształtują właściwe postawy wobec dziecka. Pozytywne komunikaty ze strony najbliższego otoczenia pozwalają nastoletnim matkom poczuć się kochanymi i akceptowanymi. Wsparcie, zwłaszcza o charakterze emocjonalnym, umożliwia budowanie przynależności i pozytywnej samooceny oraz sprawowanie opieki (Żelazkowska, 2016).

Dziewczęta nieotrzymujące wsparcia są bardziej podatne na depresję, wzrasta ich poczucie winy, osamotnienia. Szerokie praktyki uświadamiania młodych dziewcząt w zakresie wychowania seksualnego podjęte w Ontario (Kanada) przyczyniły się do zwiększenia wiedzy o zdrowiu seksualnym i reprodukcyjnym oraz formach wsparcia młodych ludzi (Ontario Ministry of Health and Long-Term Care, 2008).

Nastoletnie matki w porównaniu z dojrzałymi kobietami mają mniej doświadczenia i wymagają szerszych form pomocy. Ważną rolę w przypadku młodocianych matek odgrywa wsparcie psychospołeczne obejmujące wspieranie psychologiczne i socjalne (Finlay i in., 2018). Wsparcie pozarodzinne ma charakter nieformalny i formalny. Pierwsza forma wsparcia obejmuje szerszą sieć społeczną (na przykład innych członków rodziny, przyjaciół, znajo- mych, sąsiadów, kontakty online). Formalna pomoc związana jest z korzystaniem ze wsparcia instytucji, takich jak przychodnie zdrowia, szkoła, poradnie psychologiczno-pedagogiczne, organizacje pozarządowe ukierunkowane na pomoc rodzinie (Zbierzchowska, 2020). Ważne dla kobiet jest również wsparcie finansowe. Młoda matka ma wówczas świadomość, że będzie mogła zaspokoić potrzeby swoje i dziecka. Wsparcie instrumentalne wiąże się z udzielaniem rad, wskazówek. Młodociane dziewczyny nabieraja przekonania, że będą mogły dobrze wypełniać swoje obowiązki i zatroszczyć się o dziecko.

Celem pomocy psychologicznej jest wspomaganie młodej dziewczyny w rozwijaniu samokontroli, umiejętności emocjonalnych, empatii (Kheswa, 2019). Badania prowadzone przez Kennetha Grubera (2012) ukazują znaczenie budowania sieci wsparcia w aspekcie szkolnym, społecznym i rodzinnym. Tworzona sieć wsparcia pozwala nastoletnim matkom radzić sobie ze stresem (Wilks, Spivey, 2010). Badania prowadzone przez Annę Odrowąż-Coates i Dagmarę Kostrzewską (2021) pozwoliły dostrzec sukcesy nastoletnich matek w realizacji swojej roli dzięki korzystaniu ze wsparcia osób bliskich i pracownika socjalnego. Młode matki, jak wskazują wyniki badań, poradziły sobie ze stygmatyzacją i stereotypami. Uzyskały niezależność, samodzielność.

Ważna dla młodych matek okazuje się również wiara w siebie, swoje umiejętności. Pozwala im szybciej wrócić do równowagi psychicznej. Urodzenie dziecka w młodym wieku jest postrzegane przez kobietę jako dobra lekcja życiowa, szansa na rozwój, osiągnięcie sukcesu życiowego. Niewielkie wsparcie lub jego brak może jednak powodować u niej rozczarowanie, bezradność i trudności, które niekorzystnie wpływają na zdrowie psychiczne. Często prowadzi to do przerywania edukacji, niskiego poczucia własnej wartości, wykluczenia społecznego.

Deevia Bhana, Robert Morrell, Tamara Shefer, Sisa Ngabaza (2010) wykazali, że wsparcie nauczycieli ma duże znaczenie dla kontynuacji edukacji przez nastoletnie matki. Postawa opiekuńcza i wychowawcza nauczycieli pomaga nastolatkom radzić sobie z zażenowaniem i wstydem. 


\section{PODSUMOWANIE}

Macierzyństwo to niewątpliwie jedno z ważniejszych doświadczeń w życiu kobiety, szczególnie w społeczeństwach tradycyjnych. Wiąże się z biologiczną naturą, kulturowymi i społecznymi oczekiwaniami. Podjęcie roli matki wymaga dokonania reorganizacji pewnych planów życiowych, ustalenia nowych priorytetów, a także stworzenia nowej przestrzeni życiowej (Rubin, 1984).

Społeczeństwa zachodnie coraz częściej postrzegają nastoletnie macierzyństwo jako ważny, a zarazem poważny problem. Zostanie matką przed osiagnięciem pełnoletniości wiąże się z koniecznością przyjęcia odpowiedzialności za dziecko i zmianą tożsamości. Ciąża nastoletnich dziewcząt jest postrzegana jako zdarzenie, które znacząco zaburza funkcjonowanie oraz przyczynia się do załamania prawidłowej linii dotychczasowego rozwoju młodego człowieka. Niedojrzałe, nieprzygotowane do podjęcia nowej roli dziewczęta bywają zaskoczone faktem posiadania dziecka (Włodarczyk, 2009). Macierzyństwo wśród nastolatek wiąże się z jednej strony z dostosowaniem do zadań rozwojowych (kontynuowaniem edukacji, kształtowaniem tożsamości, tworzeniem własnego światopoglądu), a z drugiej strony - z wymaganiami rodzicielstwa (opieką, pielęgnacją, wychowaniem dziecka). Nastoletnie dziewczęta traktują ciążę jako zagrożenie mogące przyczynić się do uraty urody i figury, a także do konieczności rezygnacji z życia społecznego.

Podejmując realizację różnych obowiązków wobec dziecka, młodociane matki nie zawsze mają pewność, że będą towarzyszyć im partnerzy, rodzina czy inne osoby wspierające. Nadmiar zadań stanowi dla dziewcząt ogromną zmianę, a zarazem jest dużym obciążeniem i wyzwaniem (Skowrońska-Zbierzchowska, 2010). Wiele z nich rezygnuje $z$ kontynuowania edukacji i dalszego rozwoju, zwłaszcza że nie ma wystarczającego wsparcia ze strony bli- skich. Dodatkowo piętno bycia nastoletnią matką może nasilać tendencję młodych dziewcząt do izolacji, wykluczenia społecznego, a w konsekwencji - negatywnie wpływać na ich zdrowie psychiczne i fizyczne (SmithBattle, 2013). W skrajnych przypadkach młode matki moga unikać wychodzenia z domu i zaprzestać poszukiwania wsparcia. Czasami zdarza się, że izolują się od przyjaciół i znajomych z obawy przed mogącymi powstać plotkami.

Nastoletnie macierzyństwo jest często tematem pomijanym w społecznych dyskusjach. Brak adekwatnego poradnictwa, bezradność systemów wobec narastającego problemu oraz przyzwolenie społeczne przyczyniają się do tego, że narastają pewne deficyty informacyjne uniemożliwiające podjęcie skutecznych działań pomocowych. Poważnym utrudnieniem dla młodych matek jest brak odpowiednich, długoterminowych rozwiązań systemowych, które byłby dostosowane do ciężkiej sytuacji młodych kobiet. Często podejmowane są doraźne działania pomocowe, na przykład opiekunowie prawni mogą starać się o zasiłek rodzinny, pomoc rzeczową w ośrodkach pomocy społecznej.

W wysoko rozwiniętych państwach Unii Europejskiej występuje znaczenie bardziej rozbudowana sieć wsparcia. Nastoletnie matki otrzymują zasiłki finansowe umożliwia im pozostanie w domu i podjęcie opieki nad dzieckiem. W Belgii kobiety mogą starać się o mieszkanie. W Wielkiej Brytanii jest prowadzona psychoedukacja skoncentrowana na rozwiązywaniu problemów nieletnich funkcjonujących w nowych rolach rodzicielskich, doświadczających stresu związanego z wychowaniem i opieką nad dzieckiem (Kempińska, 2017). Niewątpliwie odpowiednie wsparcie rodzinne i instytucjonalne może pomóc młodym dziewczętom przejść w okres dorosłości i podjąć obowiązki wiążące się z macierzyństwem (Formby i in., 2010), a także przyczynić się do poprawy jakości ich funkcjonowania, zarówno fizycznego, jak i psychicznego. 


\section{BIBLIOGRAFIA}

Adewole O., Otubanjo O.M. (2020), Young men's perceptions of teenage pregnancy. The Qualitative Report, 25(9), 3367-3380.

Al-Kloub M.I., Al-Zeinb H.J., Abdalrahimc M.S., Abedd M.A. (2019), Young women's experience of adolescent marriage and motherhood in Jordan. Culture, Health and Sexuality, 21(4), 462-477.

American Psychological Association (2007), Task Force on the Sexualization of Girls. Report of the APA Task Force on the Sexualization of Girls. Washington, DC: American Psychological Association. Dostępne na: http://www.apa.org/pi/wpo/sexualization.html (pobrano: 12.04.2020).

Bakiera L., Szczerbal J. (2018), Doświadczenia nastoletniego macierzyństwa a wybrane aspekty funkcjonowania dorosłych kobiet. Polskie Forum Psychologiczne, 23(1), 102-121.

Barn R., Mantovani N. (2007), Young mothers and the care system: Contextualising risk and vulnerability. British Journal of Social Work, 37(2), 225-243.

Barrense-Dias Y., Berchtold A., Suris J.C., Akre C. (2017), Sexting and the definition issue. Journal of Adolescent Health, 61(5), 544-554.

Bartkowiak E. (2015), Obraz matki i macierzyństwa w przekazach źródłowych z historii wychowania. Wychowanie w Rodzinie, 12(2), 271-294.

Baxter AJ., Dundas R., Popham F., Craig P. (2021), How effective was England's teenage pregnancy strategy? A comparative analysis of high-income countries. Social Science and Medicine, 270, 1-9.

Bhana D., Morrell R., Shefer T., Ngabaza S. (2010), 'South African teachers' responses to teenage pregnancy and teenage mothers in schools'. Culture, Health and Sexuality, 12(8), 871-883.

Bidzan M. (2013), Nastoletnie rodzicielstwo. Perspektywa psychologiczna. Gdańsk: Harmonia Universalis.

Borecka-Biernat D. (2011), Zaburzenia w zachowaniu dzieci i młodzieży w kontekście trudnych sytuacji szkolnych i pozaszkolnych. Kraków: Oficyna Wydawnicza Impuls.

Brunton, G., Wiggins, M., Oakley, A. (2011). Becoming a mother: A research synthesis of women's views on the experience of first time motherhood. London: EPPI Centre, Social Science Research Unit, Institute of Education, University of London.

Chemutai V., Nteziyaremye J., Wandabwa G.J. (2020), Lived experiences of adolescent mothers attending Mbale Regional Referral Hospital: A phenomenological study. Hindawi Obstetrics and Gynecology International, 11, 1-12.

Clemmens D. (2003), Adolescent motherhood: A meta-synthesis of qualitative studies. The American Journal of Maternal/Child Nursing, 28(2), 93-99.

Connolly J., McIsaac C. (2009), Romantic relationships in adolescence. W: R.M. Lerner, L. Steinberg (eds.), Handbook of Adolescent Psychology, 104-151. Hoboken, NJ: Wiley and Sons.

Cox S.M., Lashley C.O., Henson L.G., Medina N.Y., Hans S.L. (2021), Making meaning of motherhood: Self and life transitions among African American adolescent mothers. American Journal of Orthopsychiatry, 91(1), 120-131.

Dankiewicz-Berger M., Cendal S. (2019). „Macierzyństwo nowoplemienne” - analiza jakościowa parentingowych komunikatów internetowych. Annales Universitatis Paedagogicae Cracoviensis. Studia Psychologica, 12, 237-258.

Deręgowska J., Majorczyk M. (red.) (2012), Konteksty wspótczesnego macierzyństwa. Perspektywa młodych naukowców. Poznań: Wydawnictwo Naukowe Wyższej Szkoły Nauk Humanistycznych i Dziennikarstwa.

Dobrołowicz J., Garbat A., Pak A. (2018), Macierzyństwo i ojcostwo w warunkach zmiany społeczno-kulturowej. Od wyobrażeń do rzeczywistości. Kielce: Uniwersytet Jana Kochanowskiego.

Dodaj A., Sear K. (2020), Sexting categories. Mediterranean Journal of Clinical Psychology, 8(2), 1-27.

Döring N. (2014), Consensual sexting among adolescents: Risk prevention through abstinence education or safer sexting. Cyberpsychology, 8(1), 1-18.

Durham M.G. (2010), Efekt Lolity. Wizerunek nastolatek we wspótczesnych mediach. Warszawa: Prószyński i S-ka.

Dziewanowska M. (2019), Kryzysowe macierzyństwo - młode matki w systemie opieki instytucjonalnej. Nauki o Wychowaniu. Studia Interdyscyplinarne, 2(9), 139-156. 
Dzwonkowska-Godula K. (2009), Macierzyństwo i ojcostwo jako nowe doświadczenie kobiety i mężczyzny. Acta Universitatis Lodziensis. Folia Sociologica, 34, 107-125.

Elder G.H. Jr. (1998), The life course as developmental theory. Child Development, 69(1), 1-12.

Ellis-Sloan K., Tamplin A. (2019), Teenage mothers and social isolation: The role of friendship as protection against relational exclusion. Social Policy and Society, 18(2), 203-218.

Ferketich, S.L., Mercer, R.T. (1995). Paternal-infant attachment of experienced and inexperienced fathers during infancy. Nursing Research, 44(1), 31-37. https://doi.org/10.1097/00006199-199501000-00007.

Finlay K.A., Peacock S., Elander J. (2018), Developing successful social support: An interpretative phenomenological analysis of mechanisms and processes in a chronic pain support group. Psychology and Health, 33(7), 846-871.

Formby E., Hirst J., Owen J. (2010), Pathways to adulthood: Reflections from three generations of young mothers and fathers. W: S. Duncan, R. Edwards, C. Alexander (eds.), Teenage Parenthood: What's the Problem?, 85-111. London: Tufnell Press.

Fromm E. (1971), O sztuce miłości. Poznań: Dom Wydawniczy Rebis.

Furman W., Shaffer L. (2003), The role of romantic relationships in adolescent development. W: P. Florsheim (ed.), Adolescent Romantic Relations and Sexual Behavior: Theory, Research, and Practical Implications, 3-22. Mahwah, NJ: Erlbaum.

Galovan A.M., Drouin M., McDaniel B.T. (2018), Sexting profiles in the United States and Canada: Implications for individual and relationship well-being. Computers in Human Behavior, 79, 19-29.

Graham H., McDermott E. (2005), Qualitative research and the evidence base of policy: Insights from studies of teenage mothers in the UK. Journal of Social Policy, 35(1), 21-37.

Gruber K.J. (2012), A comparative assessment of early adult life status of graduates of the North Carolina Adolescent Parenting Program. Journal of Child and Adolescent Psychiatric Nursing, 25(2), 75-83.

Hasinoff A.A. (2013), Sexting as media production: Rethinking social media and sexuality. New Media and Society, 15(4), 449-465.

Havighurst R.J. (1948). Developmental Tasks and Education. Chicago: University of Chicago Press.

Henderson J., Redshaw M. (2013). Women's experience of induction of labor: A mixed methods study. Acta Obstetricia et Gynecologica Scandinavica, 92(10), 1159-1167.

Hunt T.K., Caldwell C.H., Assari S. (2015), Family economic stress, quality of paternal relationship, and depressive symptoms among African American adolescent fathers. Journal of Child and Family Studies, 24(10), 3067-3078.

Imacka J., Bulsa M. (2012), Ryzykowne zachowania seksualne młodzieży jako czynnik zwiększający ryzyko zakażenia chorobami przenoszonymi drogą płciową. Hygeia Public Health, 47(3), 272-276.

Jalanko E., Gyllenberg F., Krstic N., Gissler M., Heikinheimo O. (2021), Municipal contraceptive services, socioeconomic status and teenage pregnancy in Finland: A longitudinal study. BMJ Open, 11:e043092.

Jones C., Whitfield C., Seymour J., Hayter M. (2019), Other girls': A qualitative exploration of teenage mothers' views on teen pregnancy in contemporaries. Sexuality and Culture, 23, 760-773.

Kempińska U. (2017), Nieletnie macierzyństwo - problem ogólnoświatowy. Poznań: Instytut NaukowoWydawniczy MAIUSCULA sp. z o.o.

Kernberg O.F. (1998), Zwiazki miłosne. Norma i patologia. Poznań: Zysk i S-ka.

Kheswa J.G. (2019). Factors and effects of work-related stress and burnout on the well-being of social workers in the Eastern Cape province, South Africa. SA Journal of Industrial Psychology, 45, 1-10.

Landers M.D., Mitchell O., Coates E.E. (2015), Teenage fatherhood as a potential turning point in the lives of delinquent youth. Journal of Child and Family Studies, 24(6), 1685-1696.

Leksy K. (2020), Młodzież we współczesnej przestrzeni społeczno-kulturowej. Wybrane aspekty zdrowotne i pedagogiczne. Warszawa: Difin.

Madlala S.T., Sibiya M.N., Nqxongo T.S.P. (2018), Perceptions of young men at the Free State School of Nursing with regards to teenage pregnancy. African Journal of Primary Health Care and Family Medicine, 10(1), 1-7.

Mangeli M., Rayyani M., Cheraghi M.A., Tirgari B. (2018), Iranian mothers' experiences of the outcomes of early motherhood: A qualitative study. Social Work in Public Health, 33(3), 163-172. 
Martinez-Prather K., Vandiver D.M. (2014), Sexting among teenagers in the United States: A retrospective analysis of identifying motivating factors, potential targets, and the role of a capable guardian. International Journal of Cyber Criminology, 8(1), 21-35.

Maslowsky J., Hendrick C.E., Stritzel H. (2021), Mechanisms linking teenage mothers' educational attainment with self-reported health at age 50. BMC Womens Health, 21(1), 1-9.

Matlakala F.K., Makhubele J.C., Mashilo M.W. (2018), Challenges of teenage fathers towards fatherhood in Vaalbank, Mpumalanga province. Gender and Behaviour, 16(3), 12013-12020.

Mazur J. (red.) (2015), Zdrowie i zachowania zdrowotne młodzieży szkolnej w Polsce na tle wybranych uwarunkowań socjodemograficznych. Wyniki badań HBSC 2014. Warszawa: Instytut Matki i Dziecka.

Medrano, J.L.J., Rosales, F.L., Gámez-Guadix, M. (2018), Assessing the links of sexting, cybervictimization, depression, and suicidal ideation among university students. Archives of Suicide Research, 22, $153-164$.

Mezmur H., Assefa N., Alemayehu T. (2021), Teenage pregnancy and its associated factors in Eastern Ethiopia: A community-based study. International Journal of Women's Health, 13, 267-278.

Mukuna R.K. (2020), Exploring Basotho teenage fathers' experiences of early fatherhood at South African rural high schools. Journal of Psychology in Africa, 30(4), 348-353.

Mulherin K., Johnstone M. (2015), Qualitative accounts of teenage and emerging adult women adjusting to motherhood. Journal of Reproductive and Infant Psychology, 33(4), 388-401.

Mushwana L., Monareng L., Richter S., Muller H. (2015), Factors influencing the adolescent pregnancy rate in the Greater Giyani Municipality, Limpopo Province - South Africa. International Journal of Africa Nursing Sciences, 2, 10-18.

Musyimi Ch.W., Mutiso V.N., Nyamai D.N., Ebuenyi I., Ndetei D.M. (2020), Suicidal behavior risks during adolescent pregnancy in a low-resource setting: A qualitative study. PLoS ONE, 15(7): e0236269.

Odrowąż-Coates A., Kostrzewska D. (2021), A retrospective on teenage pregnancy in Poland: Focusing on empowerment and support variables to challenge stereotyping in the context of social work. Child and Adolescent Social Work Journal, 38, 165-174.

Ontario Ministry of Health and Long-Term Care (2008), Initial Report on Public Health: Teen Pregnancy. Dostępne na: https://www.health.gov.on.ca/en/public/publications/pubhealth/init_report/tp.html (pobrano: 28.08.2017).

Oosten J.M. van, Vandenbosch L. (2017), Sexy online senf-presentation on social network sites and the willingness to engage in sexting: A comparison of gender and age. Journal of Adolescence, 54, 42-50.

Paschal A.M., Lewis-Moss R.K., Hsiao T. (2011), Perceived fatherhood roles and parenting behaviors among African American teen fathers. Journal of Adolescent Research, 26(1): 61-83.

Patchin J.W., Hinduja S. (2020), Sextortion among adolescents results from a national survey of US youth. Sexual Abuse, 32(1), 30-54.

Pavelová L., Archalousová A., Slezáková Z., Zrubcová D., Solgajová A., Spáčilová Z., Krištofová E., Slamková A. (2021), The need for nurse interventions in sex education in adolescents. International Journal of Environmental Research and Public Health, 18(2), 1-10.

Premberg A., Hellström A.-L., Berg M. (2008), Experiences of the first year as father. Scandinavian Journal of Caring Sciences, 22(1), 56-63.

Primus L. (2017), Changing Systems and Practice for Young Fathers to Improve Outcomes for Youth Fathers, Their Children, and Their Families. Washington, DC: Center for the Study of Social Policy.

Przybyła-Basista H., Kwiecińska E., Ilska M. (2020), Body acceptance by pregnant women and their attitudes toward pregnancy and maternity as predictors of prenatal depression. International Journal of Environmental Research and Public Health, 17(9436), 1-12.

Raley R.K., Kim Y., Daniels K. (2012), Young adults' fertility expectations and events: Associations with college enrollment and persistence. Journal of Marriage and Family, 74(4), 866-879.

Ringrose J., Harvey L., Gill R., Livingstone S. (2013), Teen girls, sexual double standards and 'sexting': Gendered value in digital image exchange. Feminist Theory, 14(3), 305-323.

Rocznik Demograficzny (2019), Warszawa: Główny Urząd Statystyczny.

Roye C.F., Balk J. (1996), The relationship of partner support to outcomes for teenage mothers and their children. Journal of Adolescent Health, 19(2), 86-93. 
Rubin K.H., Bukowski W.M., Parker J.G. (2006), Peer interactions, relationships, and groups. W: W. Damon, R.M. Lerner, N. Eisenberg (eds.), Handbook of Child Psychology: Social, Emotional, and Personality Development, s. 571-645. Hoboken, NJ: Wiley.

Rubin R. (1984), Maternal Identity and Maternal Experience. New York: Springer Publishing Co.

Sadler K. (2011), Normal adolescent development. W: M.A. Goldstein (ed.), The MassGeneral Hospital for Children Adolescent Medicine Handbook, s. 23-26. New York, NY: Springer.

Scharf M., Mayseless O. (2007), Putting eggs in more than one basket: A new look at developmental processes of attachment in adolescence. New Directions for Child and Adolescent Development, 117, 1-22.

Seglow R, Canham H. (2002), Intra-uterine life and the experience of birth. W: D. Hindle, M.V. Smith (eds), Personality Development: A Psychoanalytic Perspective ( $2^{\text {nd }}$ ed.), s. 13-32. New York: Taylor \& Francis Library.

Skowrońska-Zbierzchowska A. (2010), Doświadczenia małoletnich rodziców. Aspekty socjopedagogiczne. Gdańsk: Wydawnictwo Uniwersytetu Gdańskiego.

Skowroński B.Ł. (2013), Internet i związane z nim zagrożenia w opinii gimnazjalistów oraz ich rodziców. Seminare, 33, 221-239.

SmithBattle L. (2013), Reducing the stigmatization of teen mothers. The American Journal of Maternal Nursing, 38(4), 235-241.

Smyth L. (2020), Social roles and alienation: Breastfeeding promotion and early motherhood. Current Sociology Review, 68(6), 814-831.

Sriyasak, A., Almqvist, A-L., Sridawruang, Ch., Neamsakul, W., Häggström-Nordin, E. (2016). Struggling with motherhood and coping with fatherhood - A grounded theory study among Thai teenagers. Midwifery, 42, 1-9.

Steinberg L. (2014), Age of Opportunity: Lessons from the New Science of Adolescence. Boston: Houghton Mifflin Harcourt.

Stern D.N. (2018), The Motherhood Constellation: A Unified View of Parent-Infant Psychotherapy. New York: Basic Books.

Szukalski P. (2010), Nastoletnie macierzyństwo w Polsce - ujęcie regionalne. Praca Socjalna, 135-157.

Tracy E.M., Whittaker J.K. (1990), The Social Network Map: Assessing social support in clinical social work practice. Families in Society, 71(8), 461-470.

Vincent G., Alemu F.M. (2016), Factors contributing to, and effects of, teenage pregnancy in Juba. South Sudan. Medical Journal, 9, 28-31.

Vugt E. van, Versteegh P. (2020), "She gave me hope and lightened my heart": The transition to motherhood among vulnerable (young) mothers. Children and Youth Services Review 118, 1-8.

Ward L.M., Seabrook R.C., Manago A., Reed L. (2016), Contributions of diverse media to self-sexualization among undergraduate women and men. Sex Roles, 74, 12-23.

Whitehead E. (2001), 'Teenage pregnancy: On the road to social death'. International Journal of Nursing Studies, 38(4), 437-446.

Wilks S.E., Spivey C.A. (2010), Resilience in undergraduate social work students' social support and adjustment to academic stress. Social Work Education, 29(3), 276-288.

Włodarczyk E. (2009), Nastoletnie macierzyństwo jako problem indywidualny i społeczny. W: K. Marzec-Holka (red.), Kapitat społeczny a nierówności - kumulacja i redystrybucja, 454-463. Bydgoszcz: Wydawnictwo Uniwersytetu Kazimierza Wielkiego.

World Health Organization (2016), Maternal, Newborn, Child and Adolescent Health. Dostepne na: https:// www.who.int/maternal_child_adolescent/topics/adolescence/dev/en/ (pobrano: 27.07.2017).

World Health Organization (2020), Adolescent Pregnancy. Dostępne na: https://www.who.int/news-room/ fact-sheets/detail/adolescent-pregnancy (pobrano: 20.03.2021).

Zbierzchowska A. (2020), Rodziny pochodzenia nastoletnich matek i ojców - funkcjonowanie, zasoby, wsparcie. Pedagogika Społeczna, 19(2), 115-136.

Zurbriggen E.L., Ramsey L., Jaworski B.K. (2011), Self- and partner objectification in romantic relationships: Associations with media consumption and relationship satisfaction. Sex Roles, 64(7), 449-462.

Żelazkowska M. (2016), Wczesne macierzyństwo. Kryzys czy szansa? Olsztyn: Szkoła Wyższa im. J. Rusieckiego.

Żelazkowska M. (2018). Dojrzałość do macierzyństwa nastoletnich matek w perspektywie psychospołecznej. Przeglad Pedagogiczny, 1, 36-45. 